\title{
THE APPLICATION OF SMART CITIES CONCEPT FOR CITIZENS OF LITHUANIA AND SWEDEN: COMPERATIVE ANALYSIS \\ Gitana Dudzevičiūtè
} The General Jonas Žemaitis Military Academy of Lithuania, Vilnius Gedinimas Technical university, Lithuania E-mail: gitana.dudzeviciute@vgtu.It

Agnè Šimelytė Vilnius Gediminas Technical University, Vilniaus kolegija/University of Applied Sciences, Lithuania E-mail: agne.simelyte@vgtu.lt

Aušra Liučvaitienè Vilnius Gediminas technical university, Vilniaus kolegija/University of Applied Sciences, Lithuania E-mail: ausra.liucvaitiene@vgtu.It

Submission: $15 / 04 / 2017$

Revision: 11/05/2017 Accept: 19/05/2017

\section{ABSTRACT}

Urbanization and expansion of cities requires new tools to improve the quality of life of city inhabitants for all areas from mobility to leisure activities. Thus, technological development and digitalisation have been introduced into infrastructures such as rails, roads, airports, bridges, tunnels and communications. Policy of smart cities concept focuses on economy, people, mobility, governance, environment, and living. Even more, implemented framework of smart cities stimulates sustainable economic development. Smart economy is a trigger for innovations and entrepreneurship. Installed measures of smart mobility reduce traffic jams and optimise transportation systems.

This research attempts to compare largest different cities of Lithuania and Sweden in the context of smart cities' concept. 
Due to the shortage and mismatching statistical information, the paper is limited with only four following indicators: smart economy, smart mobility, smart environment, and smart governance. The analysis of indicators shows that Lithuanian major cities in all groups of criterion are below average while values of indicators in the case of Swedish major cities are much higher than average.

Keywords: smart city; smart economy; smart governance; smart mobility; Sweden; Lithuania

\section{INTRODUCTION}

Nowadays, in increasingly interconnected world, urbanization process can raise a variety of socio - economic, technical and organization problems. The process of urbanization describes a shift in a population from small rural areas in which agriculture is the dominant economic activity towards one where the population is concentrated in urban settlements with industrial and service activities (MONTGOMERY et al, 2004).

In 2007, for the first time in history, the world's urban population exceeded the population living in rural settlements (UNITED NATIONS, 2014). According to the statistics of United Nations (2014), today over half of the world's population lives in urban areas. The population living in cities is expected to grow.

By 2050, around 66 per cent of global population is projected to be urban. It means that due to the concentration of people in urban areas, the coming decades will bring further changes which are integrally linked to sustainable development. On the one hand, with good planning and governance, increasing urbanization can facilitate socio - economic development.

On the other hand, unplanned urban growth might threaten sustainable development when the necessary governmental policies are not implemented (UNITED NATIONS, 2014). The world has known many examples of cities that have grown rapidly without any kind of planning. The result has been chaotic and detrimental (KIM; HAN, 2012; MCKINSEY \& COMPANY, 2013; NEIROTTI et al, 2014).

As cities faces the challenges, such as performance, growth, competitiveness and others, the leaders supposed to be more flexible and forward looking, planning 
INDEPENDENT JOURNAL OF MANAGEMENT \& PRODUCTION (IJM\&P)

http://www.ijmp.jor.br

v. 8, n. 4, October - December 2017

ISSN: 2236-269X

DOI: 10.14807/ijmp.v8i4.659

for growing and changing populations and the impact on different aspects of city life such as transportation, education, health, pollution and others (MCKINSEY \& COMPANY, 2013).

Many cities leaders choose to transform cities into "smart cities". This label refers to new socio - economic environment in which population, enterprises, and governments can perform more efficiently (LETAIFA, 2015). However, the concept of Smart City (SC) is a relatively new. The context of SC concept is dependent on country, government, IT, communications, natural resources and other capacities (WEISI; PING, 2014; LETAIFA, 2015).

Many researchers (HOLLANDS, 2008; CARAGLIU et al, 2009; ALLWINKLE; CRUICKSHANK, 2011; BAKICI, 2012; HIELKEMA; HONGISTO, 2012; VANOLO, 2013; LETAIFA, 2015) have acknowledged the shortage of consensus on how to define smart cities and common methodology for assessing them. Due to the fact that cities vary across size, resources, infrastructure and other capacities, a need exists for a comprehensive framework that conceptualizes different components of a smart city, integrates the measures, and explains the strategic steps to follow (ZYGIARIS, 2012).

In this context, government supposed to implement policies to ensure sustainable urbanization which requires that cities generate better employment opportunities, greater income, and living conditions and welfare; expand the necessary infrastructure; ensure appropriate access to services; reduce the number of people at risk of poverty and social exclusion; and preserve the natural assets (UNITED NATIONS, 2014).

This research attempts to compare largest different cities of Lithuania and Sweden in the context of smart cities' concept. Due to the shortage and mismatching statistical information, the paper is bounded with only four following indicators: smart economy, smart mobility, smart environment, and smart governance. All other factors are not considered here. That is the major limitation of this paper.

The paper is organized as follows. Section 2 reviews previous studies on Smart City concept and analyses different approaches and research methodology. The investigations are summarized and the main insights are provided. On the basis of theoretical insights and statistics data, section 3 compares the Lithuanian and 
INDEPENDENT JOURNAL OF MANAGEMENT \& PRODUCTION (IJM\&P)

http://www.ijmp.jor.br

v. 8, n. 4, October - December 2017

ISSN: 2236-269X

DOI: 10.14807/ijmp.v8i4.659

Swedish cities in the context of smart cities. Section 4 concludes summarizing the main trends observed.

\section{THEORETICAL INSIGHTS REVIEW AND METHODOLOGY}

\subsection{Literature review on Smart City concept}

The concept of smart cities is very close to other similar concepts such as intelligent and creative cities. The line among these three concepts is very blurry (HOLLANDS, 2008). Historically, the concept of intelligent city has been the first. It has referred to top-down approaches with the main focus on technologies and the strong emphasis on optimization through technology (ZYGIARIS, 2012; WALRAVENS, 2015). These cities have integrated all conditions of their infrastructures such as rails, roads, airports, bridges, tunnels and communications (WALRAVENS, 2015).

The concept of creative cities highlights the opposite bottom-up approach. Such kind of cities usually relies on community-based and private sector initiatives, social entrepreneurship without a focus on coordination and a long-term vision. The initiatives of creative cities often fail to become sustainable due to the shortage of resources and formal leadership (HARTLEY et al, 2012; LETAIFA, 2014).

In recent years, the concept of smart cities has been quite popular in the policy arena (LOMBARDI et al, 2012). In the scientific literature, this has been described from different viewing angles. In smart cities context, the main focus of Giffinger et al. (2007) is on well performing and a forward-looking way in economy, people, mobility, governance, environment, and living. Hollands (2008) noted that smart cities relied on "implementation of information and communication technology (ICT) infrastructures to support social and urban growth through improving the economy, citizens' involvement and governmental efficiency".

Smart cities are the result of innovation ecosystem, which involves wideranging social interactions and educated labor force that generates value through information use (KOMNINOS, 2008; LETAIFA, 2015). According to Caragliu et al. (2009), smart cities are safe, secure, environmental and efficient urban centres with advanced infrastructures, which stimulate sustainable economic development.

Dirks and Keeling (2009) argued that a smart city consists of the urban services, and residents, transport and communication, business, water and energy 
supply systems. Moreover, the concept of smart cities relates to the use of smart computing technologies in city administration, healthcare, education, public safety, transportation, and real estate (WASHBURN et al, 2010).

Many scholars (HOLLANDS, 2008; SHAPIRO, 2008; GIRAD et al, 2009; DEAKIN, 2010; ALLWINKLE; CRUICKSHANK, 2011; LOMBARDI et al, 2012; BAKICI et al, 2012; LETAIFA, 2015) have agreed that smart cities are intelligent and creative. However, they differ from intelligent and creative cities by focusing on balance of technology, institutions and citizens. The focus is on neither a bottom-up nor top-down approaches. The concept of smart cities integrates formal leadership and democratic participation in the IT-based urban ecosystem (ZYGIARIS, 2012; LETAIFA, 2015).

Despite smart cities' focus on the role of IT infrastructure, many studies has also been carried out on the role of social and human capital and environmental factors as important drivers of urbanization process (LOMBARDI et al, 2012). It has been noted, that the term of smart cities has been used in association with various aspects, such as economy, business, education, government administration, modern technologies and other aspects referring to life in a city (GIFFINGER et al, 2007; EZKOWITZ, 2008; CARAGLIU et al, 2009; LOMBARDI et al, 2012).

Moreover, in order to assess performance of smart cities, the framework has been proposed by Lombardi et al. (2012). This framework has focused on the measurement of different aspects and linking these to the main dimensions of a smart city. These aspects have included as follows: smart economy, smart people, smart living, smart mobility, smart environment and smart governance (GIFFINGER et al, 2007; GIRARD et al, 2009; NEIROTTI et al, 2014; LETAIFA, 2015) (Table 1).

Table1: Dimensions and indicators of smart cities Smart cities dimensions

Smart economy

Smart people

Main indicators

Public expenditure on research and development, innovations and entrepreneurship, public expenditure on education, gross domestic product per capita, debt of municipal authority per resident, unemployment rate, employment rate in high tech and creative industries, annual household income, energy intensity, renewable energy, financial intermediation, culture and entertainment industry, hotels and restaurants.

Percentage of population aged 15-64 with secondary level education, percentage of population aged 15-64 with higher education, percentage of population working in education sector, city representatives per resident, foreign language skills, level of computers skills, patent applications per inhabitant, participation in life-long learning. 
ISSN: 2236-269X

DOI: 10.14807/ijmp.v8i4.659

\begin{tabular}{|c|l|}
\hline Smart living & $\begin{array}{l}\text { Health care expenditure, tourists overnights stays, museum visits, } \\
\text { cinema and theatre attendance, percentage of people undertaking } \\
\text { industry-based training, number of enterprises adopting ISO 14000 } \\
\text { standards. }\end{array}$ \\
\hline Smart mobility & City logistics, info mobility, people mobility. \\
\hline Smart environment & $\begin{array}{l}\text { Annual energy consumption, total } \mathrm{CO}_{2} \text { emissions, efficient use of } \\
\text { electricity, annual water consumption, efficient use of water, area in } \\
\text { green space, greenhouse gas emission intensity of energy } \\
\text { consumption, population exposure to air pollution, percentage of } \\
\text { population engaged in environmental activity, percentage of citizens } \\
\text { travelling to work on public transport, percentage of total energy derived } \\
\text { from renewable resources. }\end{array}$ \\
\hline Smart governance & $\begin{array}{l}\text { E- Government usage by citizens (percentage of individuals who have } \\
\text { used the Internet for interaction with public authorities in the last } 3 \\
\text { months, E-democracy (usage of innovative ICT to support ballots, green } \\
\text { and fair-trade public procurement), percentage of households with } \\
\text { Internet access at home, transparency enabling citizens to access } \\
\text { official documents in a simple way and to take part in the decision } \\
\text { processes. }\end{array}$ \\
\hline
\end{tabular}

Source: GIFFINGER et al. (2007); GIRARD et al. (2009); TOPPETA (2010); LOMBARDI et al. (2012); NEIROTTI et al. (2014); LETAIFA (2015).

Smart economy. Smart economy fosters innovations and entrepreneurship process. According to Bruneckiene \& Sinkiene (2014), "smart economy remains one of the key drivers of the smart city and one of the smart city indicators, because the city, characterized by high economic competitiveness, is assigned to smart cities". Smart economy involves innovation activity and mutual cooperation of enterprises, research institutions and the citizens in order to develop and promote innovation through these networks (BAKICl et al, 2013). Smart economy is a growing and sustainable economy (CARAGLIU et al, 2009).

Smart people. Smart people are the result of ethnic and social diversity, creativity, and engagement. Cities may offer programs and services to inhabitants in order to raise social capital and qualification (LETAIFA, 2015).

Smart living involves improving life quality in terms of services, enhancing health care, cultural facilities, attractiveness for tourists, promoting social cohesion, and safety (TOPPETA, 2010; LETAIFA, 2015).

Smart mobility relates with urban planning which enables to achieve smart mobility. Urban planning focuses on collective modes of transportation through the extensive use of information and communications technologies (TOPPETA, 2010; LOMBARDI et al, 2012; LETAIFA, 2015).

Smart environment. This dimension involves the indicators, such as energy consumption, and population exposure to air pollution, population engaged in 
environmental activity, energy derived from renewable resources and the use of innovative technologies, which enhance the natural environment.

Smart governance includes e-services and social media in order to enhance citizens' empowerment and involvement in public management and transparent decision-making processes leading to smart governance (NEIROTTI et al, 2014).

It should be noted that in scientific literature, all the identified dimensions of smart cities are treated as equivalent; however Chourabi et al. (2012) point out that "separate smart city components in different periods and under certain conditions have a different impact on both the rest of the components and the smart city initiative itself" (BRUNECKIENE; SINKIENE, 2014).

To sum up, scientific literature review has revealed that there is no agreement on the exact definition of a smart city. However, a number of the main indicators describing smart cities' performance have been identified.

\subsection{Methodology and data}

In order to measure the level of the smartness of cities, the comparative analysis of the major Swedish (Stockholm, Gothenburg, and Malmö) and Lithuanian cities (Vilnius, Kaunas) has been performed.

Smart economy, smart environment, smart mobility, and smart governance have been selected for the analysis. For obtaining detailed and more precisely results, each of these criterion groups is divided in the sub-criteria (Table 2).

Table 2: Dimensions of Smart City

\begin{tabular}{|l|l|}
\hline Smart cities dimensions & \multicolumn{1}{c|}{ Main indicators } \\
\hline Smart economy & $\begin{array}{l}\text { Real GDP per capita, unemployment rate, annual household income, } \\
\text { number of hotels and restaurants, percentage of population working in } \\
\text { education sector, level of computers skills, health care expenditure. }\end{array}$ \\
\hline Smart mobility & City logistics, info mobility, people mobility \\
\hline Smart environment & $\mathrm{CO}_{2}$, percentage of citizens travelling to work on public transport \\
\hline Smart governance & Percentage of households with Internet access at home \\
\hline
\end{tabular}

Source: compiled by the authors

The selection of indicators is limited by the availability, quality and the volume of statistical information. After the analysis on available information in the official statistics databases, mismatching data needed for assessing the smart cities of Sweden and Lithuania has been noticed (Table 3). 
INDEPENDENT JOURNAL OF MANAGEMENT \& PRODUCTION (IJM\&P)

http://www.ijmp.jor.br

v. 8, n. 4, October - December 2017

ISSN: 2236-269X

DOI: 10.14807/ijmp.v8i4.659

Table 3: Selected indicators for comparative analysis of Swedish and Lithuanian cities

\begin{tabular}{|c|c|c|c|}
\hline $\begin{array}{l}\text { Smart cities } \\
\text { dimensions }\end{array}$ & Main indicators & Sweden & Lithuania \\
\hline Smart economy & $\begin{array}{l}\text { GDP per capita, } \\
\text { unemployment rate, } \\
\text { annual household } \\
\text { income, number of } \\
\text { hotels and restaurants, } \\
\text { percentage of } \\
\text { population employed in } \\
\text { education sector, level } \\
\text { of computers skills, } \\
\text { expenditure on health } \\
\text { care. }\end{array}$ & $\begin{array}{l}\text { GDP per capita, } \\
\text { unemployment rate, } \\
\text { annual household } \\
\text { income, percentage of } \\
\text { population employed in } \\
\text { education sector. }\end{array}$ & $\begin{array}{l}\text { GDP per capita, } \\
\text { unemployment rate, } \\
\text { number of hotels and } \\
\text { restaurants. }\end{array}$ \\
\hline Smart mobility & $\begin{array}{l}\text { City logistics, info } \\
\text { mobility, people } \\
\text { mobility }\end{array}$ & People's mobility & $\begin{array}{l}\text { City logistics, people's } \\
\text { mobility }\end{array}$ \\
\hline Smart environment & $\begin{array}{l}\mathrm{CO}_{2} \text {, percentage of } \\
\text { citizens travelling to } \\
\text { work by public } \\
\text { transportation }\end{array}$ & $\begin{array}{l}\mathrm{CO}_{2} \\
\text { Areas covered by } \\
\text { forests or green zones }\end{array}$ & $\begin{array}{l}\mathrm{CO}_{2} \text {, percentage of } \\
\text { citizens travelling to } \\
\text { work by public } \\
\text { transportation } \\
\text { Areas covered by } \\
\text { forests or green zones }\end{array}$ \\
\hline Smart governance & $\begin{array}{l}\text { Percentage of } \\
\text { households with } \\
\text { Internet access at } \\
\text { home }\end{array}$ & $\begin{array}{l}\text { Percentage of } \\
\text { households with } \\
\text { Internet access at } \\
\text { home }\end{array}$ & $\begin{array}{l}\text { Percentage of } \\
\text { households with } \\
\text { Internet access at } \\
\text { home }\end{array}$ \\
\hline
\end{tabular}

Source: compiled by the authors

Thus, such information limitations reduce the scope of criterion groups, which defines the smart city. Even more, statistical information of separate criterion is available within the different period of time. The Report on Smart Cities (2014) (EUROPEAN MEDIUM-SIZED CITIES..., 2014; LARGER EUROPEAN CITIES..., 2015), covers profiles and information about European small and medium size cities (Jönköping and Eskilstuna of Sweden and Kaunas of Lithuania). Meanwhile, the largest cities of European countries (Stockholm, Gothenburg, and Malmö of Sweden; and Vilnius and Kaunas of Lithuania) are included in 2015 report.

To sum up, the shortage, quality and volume of data, result the differences in various studies on smart cities. Thus, this circumstance implies that the improvement of data collection and information system might ensure the continuity of smart city assessment.

The aim of analysis is to compare the smartness of Swedish and Lithuanian cities (Stockholm, Gothenburg, and Malmö of Sweden; and Vilnius and Kaunas of Lithuania). Data from Statistics Lithuania, PLEEC project of 2013-2015 and European City Model of 2013-2015, compiled by the TUWIEN research group has 
INDEPENDENT JOURNAL OF MANAGEMENT \& PRODUCTION (IJM\&P)

http://www.ijmp.jor.br

v. 8, n. 4, October - December 2017

ISSN: 2236-269X

DOI: 10.14807/ijmp.v8i4.659

been used for the research. The summarised profiles of 70 medium-sized cities, the assessment of which is based on 81 indicators, are available in the reports of the PLEEC project (PLEEC PROJECT..., 2016). The profiles of the 90 larger cities (71 medium-sized cities were involved in the research of 2013, while 77 medium-sized cities were involved in the research of 2014, respectively) are available in the reports (LARGER EUROPEAN CITIES, 2015). These researches form an all-embracing viewpoint towards the profile of Smart Cities.

For comparing development of major Swedish and Lithuanian cities, the statistical data from OECD Statistics Database and Statistics Lithuania has been used. The designation and comparison of the development trends of Stockholm, Gothenburg, and Malmö of Sweden; and Vilnius and Kaunas of Lithuania is carried out according to the four criteria: smart economy, smart mobility, smart environment, and smart governance. Real GDP per capita and unemployment define smart economy, people mobility is used to assess smart mobility, amount of $\mathrm{CO}_{2}$, areas covered by forests or green areas describe smart environment; while smart governance is defined as a percentage of households with Internet access at home.

\section{THE INTERPRETATION OF COMPARATIVE ANALYSIS}

The rapid process of urbanization led to expansion of major cities. Almost 52 $\%$ of the world population lives in cities. In 2014, $41 \%$ of the population of the European Union also lived in cities. During the same year, 35\% of Swedes and 42\% of Lithuanians were the residents of cities. These differences are the result of the change of the overall population in those countries during the period of 2010-2016 (Figure 1).

The tendency shows that number of inhabitants has increased in all main cities, except Kaunas, during 2010-2016. Accordingly, the area occupied by these cities has not changed during the period of the analysis (Stockholm - 7106,87 km²; Gothenburg - 3850,19 km²; Malmö - 868,65 km²; Vilnius - 401 km²; Kaunas - 157 $\left.\mathrm{km}^{2}\right)$. 


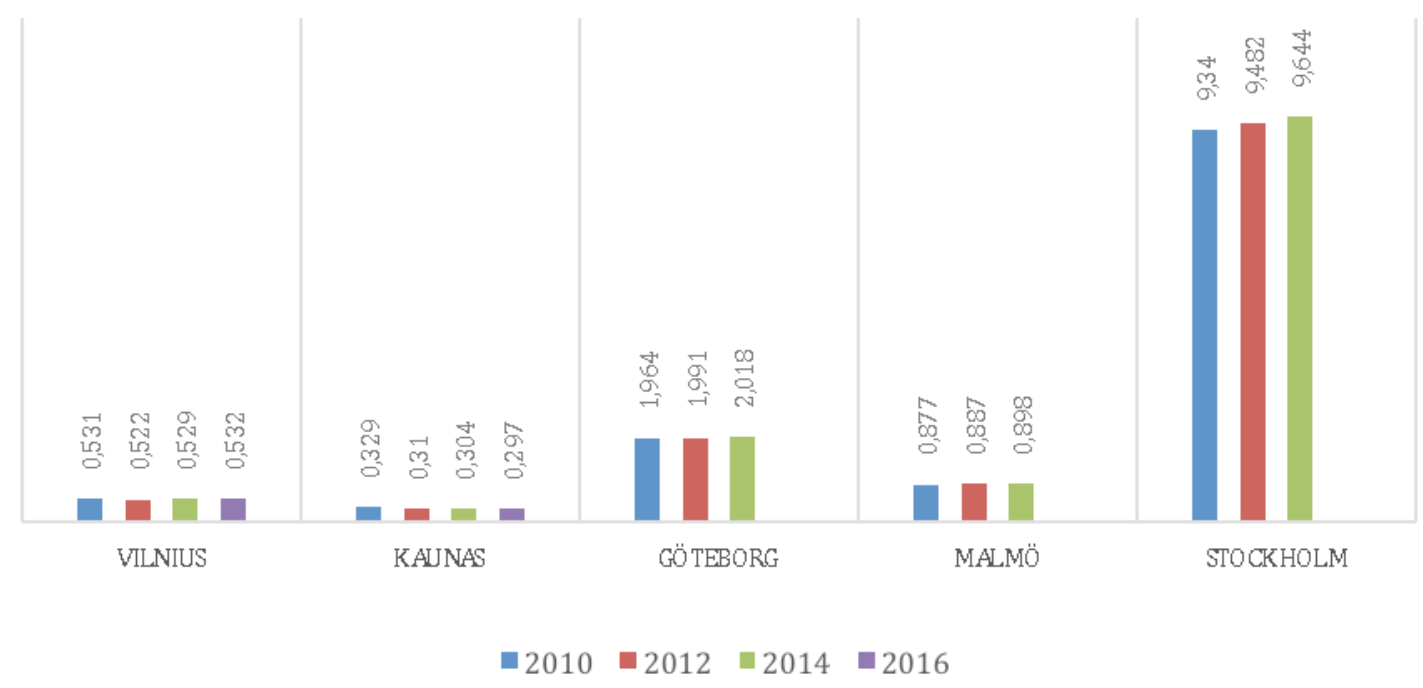

Figure 1: The change of the population in the major Lithuanian and Swedish cities during the period of $2010-2016$, in millions

Source: (OECD statistics and Statistics Lithuania)

The largest cities attract more educated, innovative, and competitive employees. During the period of 2010-2014, the general trend of employed people continued to grow - an average of $4 \%$ in Sweden and an average of $6 \%$ in Lithuania, respectively. The changes in tendencies are similar in the major cities. The biggest companies are concentrated in the major cities. Thus, the demand and supply of labour is increasing, which attracts more investments and increases the number of the innovations in research and development (Figure 2).

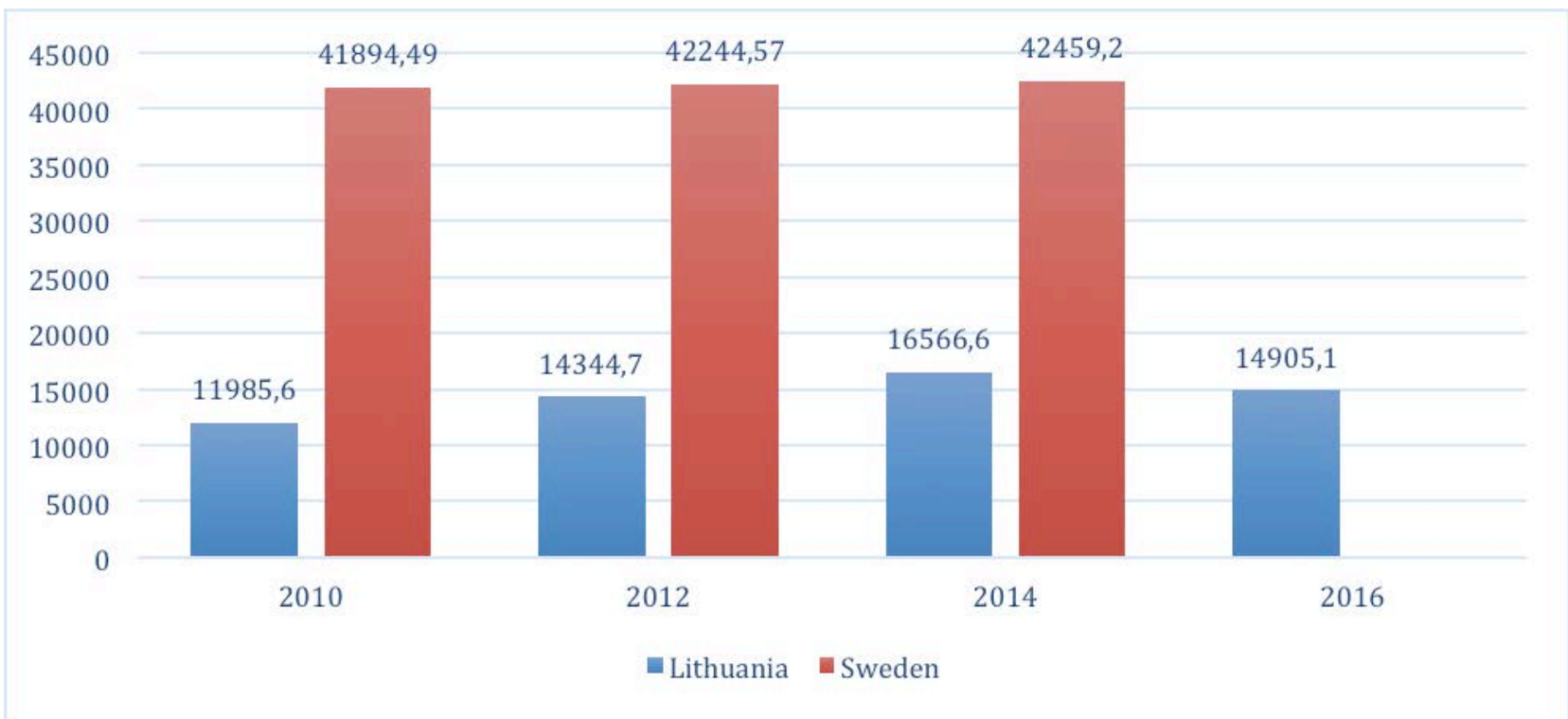

Figure 2: Real GDP per capita in USD

Source: (OECD statistics and Statistics Lithuania) 
The obvious differences in real GDP per capita result in the possibilities to use the growth of economy and its potential in the various sectors of activity. According to analysis, the growth of the Lithuanian economy is one of the most rapid in the European Union. However, compared with Swedish GDP growth in 2016, a decreasing trend is visible.

The level of digitization of a country and cities is influenced by the possibilities to use information technologies. One of the main objectives is the dissemination and availability of information to cities inhabitants and possibilities to apply smart technologies in a general system of a city. The wireless Internet hotspots, highspeed Internet, and a general development of an infrastructure (an establishment of a smart house, e-ticket, e-baking, e-government, etc.) would allow implementing these objectives. This analysis employs indicators, which are most commonly used with the aim to measure an effect of digitization in terms of a smart city. Thus, a computer use, an Internet access, and application of information technologies in general have been taken in account (Table 4).

Table 4: The percentage of households owning personal computer and using Internet in largest Lithuanian cities

\begin{tabular}{|l|c|c|c|c|}
\hline Indicator I year & $\mathbf{2 0 1 0}$ & $\mathbf{2 0 1 2}$ & $\mathbf{2 0 1 4}$ & $\mathbf{2 0 1 6}$ \\
\hline Computer & 71.2 & 72.1 & 73.9 & 78.4 \\
\hline Internet access & 71.5 & 71.1 & 73.3 & 79.0 \\
\hline $\begin{array}{l}\text { Broadband } \\
\text { internet access }\end{array}$ & 69.0 & 70.6 & 72.7 & 78.7 \\
\hline
\end{tabular}

Source: (Statistics Lithuania)

Analysed data revealed significant differences among age groups in interest and application of IT. Most users of such technologies are inhabitants at age of 1624 and represent more than $90 \%$ of all IT users. It might be assumed that senior people find to use the information technologies too difficult. Thus, it complicates the evaluation of possibilities in using smart devices and their actual benefits.

The possibilities to use smart technologies cover various activities. Still, effect achieved (lower taxes, time saved, resources saved, etc.) remains the most significant aspect while assessing their benefits. Most of the major cities are forced to solve problems of adaptability to senior residents needs by ensuring possibilities to use public spaces, transport, and buildings under conditions of limited mobility (movement disability, driving license restrictions, lack of parking spots, promotion of bicycles, etc.). The differences in Lithuania and Sweden are presented in table 5. 
Table 5: The use of the means of transport in the capital cities of Lithuania and Sweden in the year 2015. Presented as a percentage.

\begin{tabular}{|l|l|l|}
\hline Indicators & Lithuania & Sweden \\
\hline Car use in European cities & 50 & 9 \\
\hline $\begin{array}{l}\text { Public transport use in } \\
\text { European cities }\end{array}$ & 45 & 65 \\
\hline Cycling in European cities & 3 & 18 \\
\hline
\end{tabular}

Source: The State of the European Cities 2016

The presented data suggests, that Lithuanians use public transport services less often than the Swedes do. The notion, that $71 \%$ of Lithuanians and $80 \%$ of Swedes are satisfied with the public transport services, reflects the popularity of such services. During period of 2010-2015, in Lithuanian major cities number of inhabitants using the city transport has increased substantially: by $13 \%$ in Vilnius and by $11 \%$ in Kaunas, respectively.

For reducing mobility problems in Vilnius, a traffic flow monitoring and regulation system has been installed, which enabled to renovate and combine all the traffic lights of the city into one-traffic management centre. After installation of the system, the average length of a trip has decreased, despite the fact that, over the last decade, the number of vehicles in Vilnius has increased by $40 \%$. In Vilnius public transport network has become smarter as well. The electronic ticket-card has been introduced, buses and trolleybuses routes have been re-planned more effectively, and new rapid bus routes have been introduced.

Taking the aforementioned data into account, it might be stated that the volume of $\mathrm{CO}_{2}$ emissions polluting the environment in Lithuania has not contributed much to fulfilling the requirements related to preserving the nature. In 2010, the green gas emissions amounted to more than 63 tonnes, while in 2015 the $\mathrm{CO}_{2}$ emissions amounted to more than 65 tonnes, respectively. In Sweden, the volume of the $\mathrm{CO}_{2}$ emissions was reduced from 7,94 tonnes in 2000 to 7 tonnes in 2008.

Increasing the number of city residents results in reducing the green zones. The growing need for the residential or office buildings and the scale of constructions are the alternatives to these areas (Figure 3). 
DOI: 10.14807/ijmp.v8i4.659

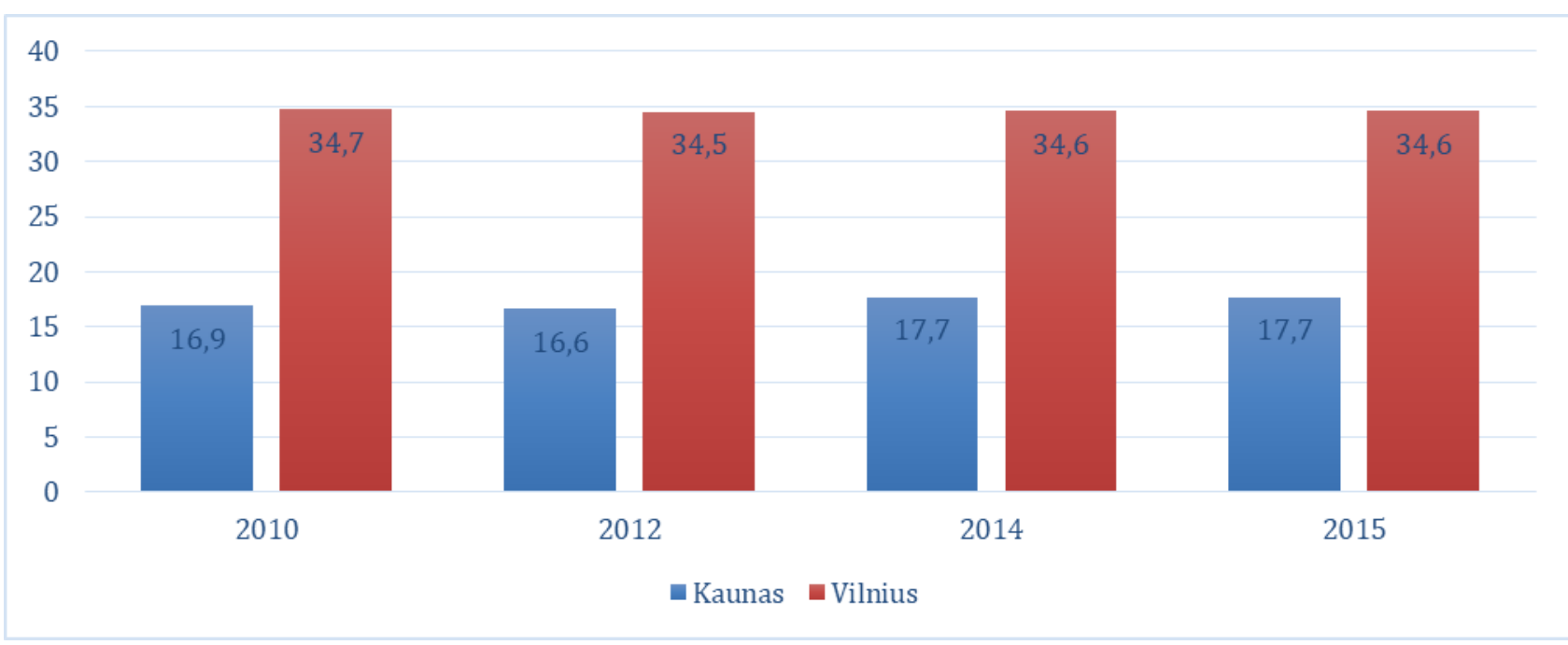

Figure 3: The areas of the major cities of Lithuania covered by forests in 2010-2015, in percentage Source: (Statistics Lithuania)

It is noticed that size of green zones in Lithuanian cities have not changed much or remained stable during the analysed period. This may be due to fact that construction of residential and industrial buildings is expanding to territories outside the city. When analysing the area of the green zones of Sweden per capita, a decreasing trend of has been observed, which is adequate to growth of population (Figure 4).

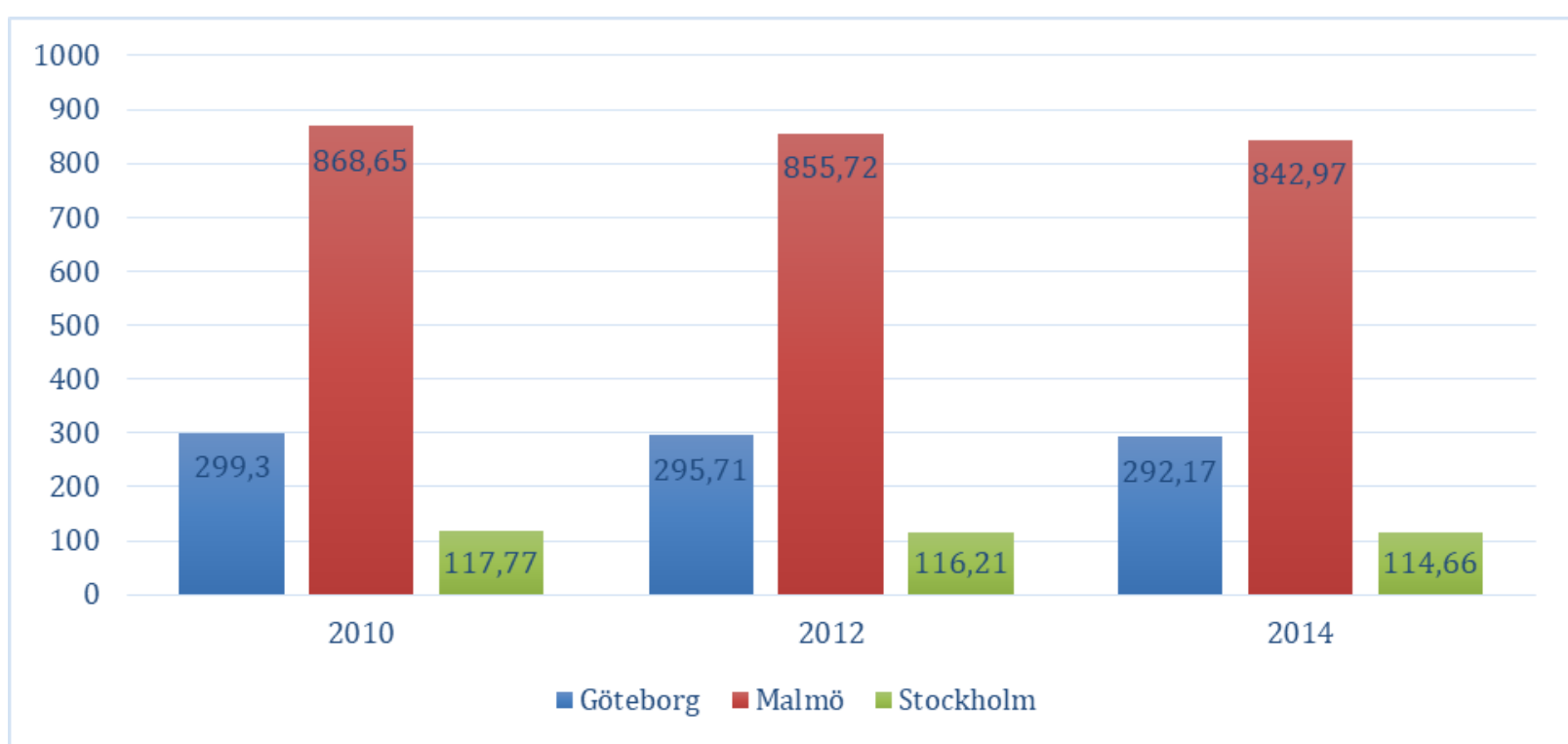

Figure 4: The area of the green zones in the major cities of Sweden in 2010-2014, in $\mathrm{m}^{2}$ per capita

Source: (OECD statistics)

Growing number of city inhabitants, better interconnections and communications result a development of smart technologies to the territories outside 
INDEPENDENT JOURNAL OF MANAGEMENT \& PRODUCTION (IJM\&P)

http://www.ijmp.jor.br

v. 8, n. 4, October - December 2017

ISSN: 2236-269X

DOI: 10.14807/ijmp.v8i4.659

a city. Thus, it might be assumed that these changes are related to the changes in labour and real estate markets.

Furthermore, the impact of digitalisation, in the concept of smart city, is measured as quality and possibilities to use e-services on governmental and municipality levels. In Vilnius, the institutions providing the first level and the second level services via the Internet have taken a dominant position during a period of analysis. This might be explained due to increase the scope of services provided via the Internet on third-fifth level. Even more, it is encouraged by increasing number of households, which owned personal computers and has the Internet access in major Lithuanian cities. Vilnius has employed the means of smart governance. The city website has been designed, which provides possibility for residents of the city to communicate with the politicians, to express their opinion in polls, and to submit electronic petitions, other proposals.

The mentioned changes in a public sector required additional investments, which allowed ensuring the smoothness of digitization process and actual benefits for the city residents that use these services. In 2015, the recent investments represented 50\% in Sweden, 30\% in Lithuania, and 42\% in the 28 member states of the European Union, respectively. However, in Lithuania inward FDI are even below the average investment amounts in the European Union. An efficiency of public administration reflects on current situation (Efficiency of public administration): 68\% in Sweden and $44 \%$ in Lithuania, respectively. A similar trend remained while analysing the quality of life in these countries. According to the data of OECD, in $2015,97 \%$ of Swedes and $75 \%$ of Lithuanians, respectively, were satisfied about their quality of life (Life satisfaction in European cities).

When analysing the collected data on the cities, which participated in the PLEC project and the data of the reports of the TUWIEN research group, two major cities of Lithuania (Kaunas and Vilnius) and three major cities of Sweden (Stockholm, Gothenburg, and Malmö) are highlighted. The results presented in figure 5 indicate summarised meanings of respective indicators, which define the smart economy, smart mobility, smart environment, and smart governance in analysed cities. 


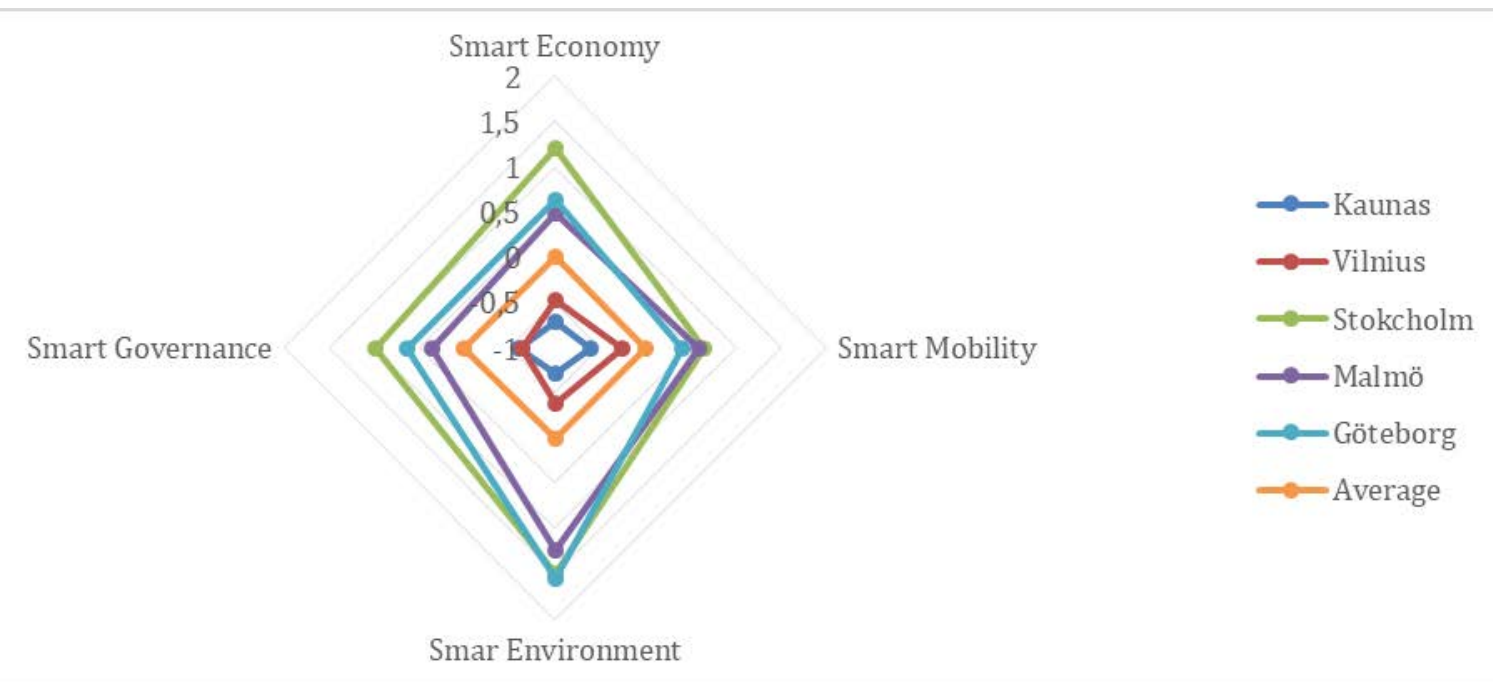

Figure 5: The comparison of the smartness indicators of Kaunas, Vilnius, Stockholm, Gothenburg, and Malmö in 2015

Source: compiled by the authors according to the data the PLEEC project and the TUWIEN report

The graph indicates that results in groups of smart economy, smart governance, and smart environment of Vilnius and Kaunas are similar. In smart mobility group, results of Vilnius and Kaunas are differed, since Vilnius is the only city of Lithuania, which has a positive city population size growth indicator. Accordingly, results of Swedish cities are similar in the groups of smart mobility, and smart environment. The smart economy and smart governance results of Stockholm differed from the results of the other analysed cities in Sweden. Comparison of Gothenburg and Malmö reveals that indicators of these cities are similar in the context of smart city.

After comparing the results of smartness indicators in Lithuania and Sweden, it might be stated, that the results of Lithuanian major cities are lower than the average, while the results of Swedish major cities are much higher than the average. However, it is noticed that the analogical results of the smartness are in the capital cities of these two countries. The changes in trends of their results are similar. The values are much higher than those of other cities in the context of smart city. It might be explained due to the fact there is a higher concentration of companies and labour force, possibilities to attract investments, a concentration of authorities, and positive trend in population growth.

Taking the general trends of urbanisation and digitalisation into account, the projects on implementing smart city concept supposed to be improved or implemented faster (to expand the system of smart governance, to upgrade the 
m.Ticket and m.Parking applications, to renovate the public transport fleet, etc. in Vilnius). However, it might be admitted that implementing the concept of smart city would not ensure a positive effect in itself. In order to solve these problems, it is necessary to use modern information technologies and employ smart solutions for improving quality of life of city residents.

\section{CONCLUSIONS}

The review of various studies reveals that there is no single accepted model of a smart city used in practice. Even more, it remains debatable the level of smartness in every criterion (smart economy, smart mobility, smart governance, smart people, smart living, and smart environment). The definition of each group of indicators and even the number of indicators, in the context of smart city, has not been provided in scientific literature yet.

In most cases, only the available results of the rankings of cities are used in the comparative analysis and the rankings of cities and countries in the lists are statistically compared as well. The indicators of chosen cities of Sweden and Lithuania are different: the values of the indicators of Stockholm, Gothenburg, and Malmö are positive in all of the groups, while opposite results are obtained in the case of the Lithuanian cities. The least differences in values are identified while analysing the indicators of the cities in each country. Varying levels of the development of the countries, growth rate of economy, possibilities to use modern technologies, and conditions for innovations and investments might be described as main causes.

Due to the shortage and availability of data, the comparison has been limited. It has been noticed that in Lithuania the data needed for evaluation of smart city, is not stored and even not collected annually in centralised manner. Thus, in order to assess the improvement of city smartness or country smartness, the databases supposed to be improved and new indicators supposed to be introduced.

\section{REFERENCES}

ALLWINKLE, S.; CRUICKSHANK, P. (2011) Creating smarter cities: an overview. Journal of Urban Technology, v.18, n. 2, p. 1-16.

BAKICI, T.; ALMIRALL, E.; WAREHAM, J. (2012) A smart city initiative: the case of Barcelona. Journal of the Knowledge Economy v. 4, n. 2, p. 135-148. 
BRUNECKIENE, J.; SINKIENE, J. (2014). Critical analysis of approaches to smart economy. 8 th International Scientific Conference "Business and Management 2014" May 15-16, 2014, Vilnius, Lithuania: 886- 894. http://dx.doi.org/10.3846/bm.2014.106.

CARAGLIU, A.; DEL BO, C.; NIJKAMP, P. (2009) Smart cities in Europe. Vrije Universiteit. Faculty of Economics and Business Administration. Available on Internet: https://ideas. repec.org/p/vua/wpaper/2009-48.html.

CHOURABI, H.; NAM, T.; WALKER, S.; GIL-GARCIA, J. R.; MELLOULI, S.; NAHON, K.; PARDO, A. T.; SCHOLL, H. J. (2012) Understanding smart cities: an integrative framework. 45th Hawaii International Conference on System Sciences, p.p 2289-2297.

DIRKS, S.; KEELING, M. (2009) A vision of smarter cities: how cities can lead the way into a prosperous and sustainable future. NY: IBM Global Business Services.

EZKOWITZ, H. (2008) The triple helix: university, industry and government. Routledge, London.

EUROPEAN SMART CITIES (2014) European medium-sized cities. Available: http://www.smart-cities.eu/index. php?cid=3\&ver=3

EUROPEAN SMART CITIES (2015) Lager European cities. Available: http://www.smart-cities.eu/index. php?cid $=6 \& v e r=4 \& c i t y=174$

GIFFINGER, R.; FERTNER, C.; KRAMAR, H.; KALASEK, R.; PICHLERMILANOVIC, N.; MEIJERS, E. (2007) Smart cities - ranking of European medium-sized cities (report), Vienna University of Technology. Available on Internet: http://www.smart-cities.eu/download/smart_cities_final_report.pdf.

GIRARD, F. L.; LOMBARDI, P.; NIJKAMP, P. (2009) Creative urban design and development. International Journal of Services Technology and Management, $v$. 13, n. 2-3, p. 111-115.

HARTLEY, J.; POTTS, J.; MACDONALD, T. (2012) Creative city índex. Cultural Science Journal, v. 5, n. 1, p. 33-45.

HIELKEMA, H.; HONGISTO, P. (2012) Developing the Helsinki smart city: The role of competitions for open data applications. Journal of the Knowledge Economy, v. 4, n. 2, p. 190-204.

HOLLANDS, R. (2008) Will the real smart city please stand up? City, v. 12, n. 3, p. 303-320.

KIM, H. M.; HAN, S. S. (2012) City profile: Seoul. Cities, v. 29, n. 2, p. 142-154.

KOMNINOS, N. (2008) Intelligent cities and globalisation of innovation networks. London and New York: Routledge.

LAZAROIU, G.C.; ROSCIA, M. (2012) Definition methodology forthesmart cities model. Energy, n. 47, p. 326-332.

LETAIFA, B. S. (2014) The uneasy transition from supply chains to ecosystems. Management Decision, v. 52, n. 2, p. 278-295.

LETAIFA, B. S. (2015) How to strategize smart cities: revealing the smart model. Journal of Business Research, v. 68, n. 7, p. 1414-1419. 
LOMBARDI, P.; GIORDANO, S.; FAROUH, H.; YOUSEF, W. (2012) Modelling the smart city performance. The European Journal of Social Science Research, v. 25, n. 2, p. 137-149.

MCKINSEY \& COMPANY (2013) How to make a city great. Available on Internet: http://www.mckinsey.com/insights/urbanization/how_to_make_a_city_great

MONTGOMERY, R. M.; STREN, R.; COHEN, B.; REED, H. E. (2004) Cities Transformed: Demographic Change and its Implications in the Developing World. London: Earthscan.

NEIROTTI, P.; DE MARCO, A.; CAGLIANO, A. C.; MANGANO, G.; SCORRANO, F. (2014) Current trends in smart city initiatives: some stylised facts. Cities, v. 38, p. 25-36.

PLEEC. (2016) Factsheet: summary of results. Available: http://www.pleecproject.eu/downloads/Reports/pleec_factsheet_summary_of_results -final.pdf

SHAPIRO, J.M. (2008) Smart cities: quality of life, productivity, and the growth effects of human capital. The review of economics and statistics, v. 88, n. 2, p. 324-335.

THE STATE OF EUROPEAN CITIES. (2016) Cities leading the way to a better future. European Commission, p. 216.

TOPPETA, D. (2010) The smart city vision: how innovation and ICT can build smart, "liveable", sustainable cities. Available on Internet: http://www.intaaivn.org/images/cc/Urbanism/background\%20documents/Toppeta_Report_005_201 0. pdf.

UNITED NATIONS. (2014) World Urbanization Prospects. New York: Department of Economic and Social Affairs.

VANOLO, A. (2013) Smart mentality: the smart city as disciplinary strategy. Urban Studies, v. 51, n. 5, p. 883-898.

WALRAVENS, N. (2015) Mobile city applications for Brussels citizens: smart city trends, challenges and a reality check. Telematics and Informatics, v. 32, p. 282299.

WASHBURN, D.; SINDHU, U.; BALAOURAS, S.; DINES, R.A.; HAYES, N.M.; NELSON, L.E. (2010) Helping CIOs understand "smart city" initiatives: defining the smart city, its drivers, and the role of the ClO. Cambridge, MA: Forrester Research, Inc.

WEISI, F.; PING, P. (2014) A discussion on smart city management based on metasynthesis method. Management Science and Engineering, v. 8, n. 1, p. 68-72.

ZYGIARIS, S. (2012) Smart city reference model: Assisting planners to conceptualize the building of smart city innovation ecosystems. Journal of the Knowledge Economy, v. 4, n. 2, p. 217-231. 